\title{
BONAPARTE'S GULL NEST NEAR SPEERS
}

CHUCK STRAUTMAN, Box 70, Speers, SK SOM 2V0

On 3 June 1997, I was helping my daughter-in-law, Janice, at Ed and Janice's farm, 10 miles north and two miles west of Speers, on the southeast quarter of section 12 , township 45 , range 12 , west of the 3rd meridian. While planting her garden, we were entertained by a weird croaking gull that was sitting on the yard transformer pole. It looked somewhat like a Franklin's Gull (Larus pipixcan) or a Laughing Gull (Larus atricilla). Janice said, "That bird has been building a nest in a spruce tree, thirty yards from the back door of the house." I checked her report; it was correct. The gull was nesting on a horizontal branch of a spruce tree, about ten feet above the ground and four feet from the trunk. When we approached the tree, the adult gull really made a racket. No early morning alarm clock was needed in the house, as each dawn this pair chattered continually. I took two pictures of the gull sitting on her nest.

About three days after the eggs hatched, the mother bird must have dropped or nudged two young gulls to the ground, and began taking them to a large slough about 500 yards from the house. As my son Ed was crossing the yard he noticed the two little yellow balls of fluff. He went to check, but the adult gull did a good job of trying to attack him and defend her young. He left them alone and they eventually reached the water.

In 1998, two year-old Bonaparte's Gulls (Larus philadelphia)appeared at the farm, but not in full adult plumage; each still had a black spot behind the eye. Two adults were with them, but I was unable to locate their nest.

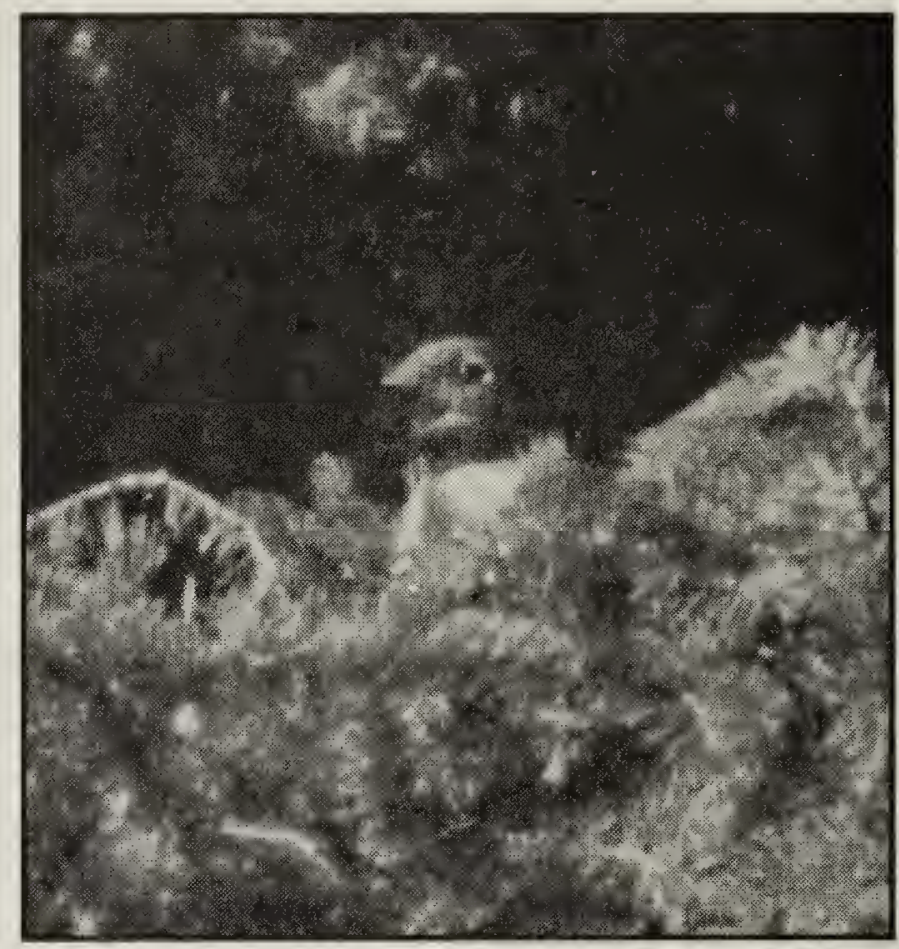

\section{Bonaparte's Gull near Speers}

In checking a book about gulls, I found that the Bonaparte's Gull normally nests in spruce trees in northern Saskatchewan, but not as far south as Speers.

I contacted Dr. Houston and forwarded the photographs. He confirmed my identification of a Bonaparte's Gull, and informed me that at this longitude this is the farthest south nest record on a tree limb. In the 1930s Bonaparte's Gulls were found and painted by the late R.D. Symons, nesting just above water in dead bulrushes (as Franklin's Gulls regularly do) in Lamotte's Swamp, in a dilatation of Jackfish Creek, north of Jackfish Lake (Symons, Blue Jay 26:70-74, 1968). Lamotte's Swamp is only about 36 miles west and 26 miles north of the Strautman farm. Dr. Houston was also unable to find any reference in the literature to young Bonaparte's Gulls leaving tree nests in the downy stage and walking such a distance to water. 